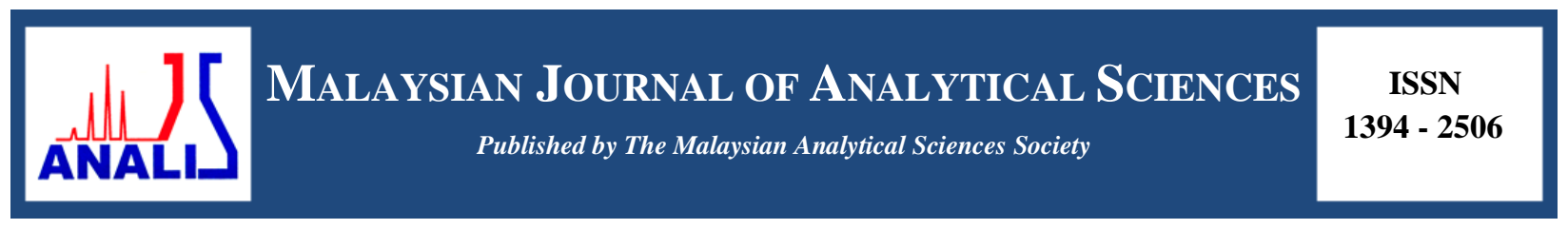

\title{
PYROLYTIC KEY INDICATORS OF BURNT PORCINE TISSUE IN THE PRESENCE OF PETROL UNDER OUTDOOR CONDITIONS
}

\author{
(Analisis Penunjuk Utama Pirolitik Tisu Khinzir Yang Dibakar Dengan Kehadiran Petrol Dalam \\ Keadaan Terbuka)
}

\author{
Gina Francesca Gabriel, Jennifer Shalini Jheyeaaseelan, Dheephikha Kumaraguru, Khairul Osman, \\ Noor Hazfalinda Hamzah* \\ Forensic Science Programme, Faculty of Health Sciences, \\ Universiti Kebangsaan Malaysia, Jalan Raja Muda Abdul Aziz, 50300 Kuala Lumpur, Malaysia \\ *Corresponding author: raviera@yahoo.com
}

Received: 15 January 2018; Accepted: 31 January 2019

\begin{abstract}
This study was conducted to provide a chemical fingerprint of burnt porcine tissue (Sus domesticus spp.) in the presence of petrol using gas chromatography-mass spectrometry (GC-MS). The pyrolysis process was followed through using two methods; in the first method, the sample was allowed to continuously burn until auto-ignition was attained and the flames self-extinguished, and in the second method, upon auto-ignition of the sample, the flame was extinguished by placing an empty lid over the tin after the size of the flame reduced to burning within the tin. Six replicates of each method were burnt outdoors and underwent passive headspace extraction using activated carbon tablets. The activated carbon tablets together with the samples were then incubated in an oven for 16 hours at $80{ }^{\circ} \mathrm{C}$. After the incubation process, the tablets were desorbed in $1 \mathrm{~mL}$ of pentane and were introduced into the GC-MS. Toluene was detected from the first method whereas 1,2,4-trimethylbenzene was detected from the second method. Pyrolytic key indicators of burnt porcine tissue in the presence of petrol were not detected under the specific environmental conditions implemented in this study. The volume of petrol together with the duration and temperature during the burning process, and the source of flame, played crucial roles in the generation and detection of pyrolytic products obtained during the fire.
\end{abstract}

Keywords: porcine bone, petrol, pyrolytic products, activated carbon tablet, gas chromatography-mass spectrometry

\section{Abstrak}

Kajian ini dijalankan untuk menjana data cap jari kimia bagi tisu khinzir (Sus domesticus spp.) yang dibakar dengan kehadiran petrol menggunakan kromatografi gas-spektrometri jisim (GC-MS). Proses pirolisis telah dijalankan mengikut dua kaedah; kaedah pertama dilakukan dengan membiarkan sampel terbakar dan apinya terpadam dengan sendiri, dan kaedah kedua, nyalaan api yang terbentuk daripada nyalaan auto pencucuhan telah dipadamkan dengan meletakkan penutup tin ke atas permukaan tin apabila saiz nyalaan api tersebut mengecil dan hanya tertumpu di dalam tin. Setiap sampel daripada kedua-dua kaedah telah dibakar secara terbuka dan menjalani proses penyerapan menggunakan penjerapan karbon teraktif dalam bentuk tablet. Proses pembakaran ini telah direplikasi sebanyak enam kali. Penjerapan karbon teraktif bersama sampel diinkubasi di dalam ketuhar selama 16 jam pada suhu $80^{\circ} \mathrm{C}$. Selepas proses inkubasi, tablet tersebut dinyaherap dalam $1 \mathrm{~mL}$ pentana dan dianalisa menggunakan GC-MS. Toluena dikesan daripada kaedah pertama manakala 1,2,4-trimetilbenzena dikesan daripada kaedah kedua. Petunjuk utama pirolitik tisu khinzir tidak dapat dikesan di bawah keadaan persekitaran spesifik yang diaplikasikan dalam kajian ini. Di samping itu, didapati bahawa isipadu petrol yang dibakar, tempoh pembakaran dan suhu yang dicapai semasa proses pembakaran serta sumber api memainkan peranan yang penting dalam menentukan kehadiran petunjuk utama produk pirolitik yang terhasil daripada sesuatu proses pembakaran. 


\title{
Gabriel et al: PYROLYTIC KEY INDICATORS OF BURNT PORCINE TISSUE IN THE PRESENCE OF PETROL UNDER OUTDOOR CONDITIONS
}

Kata kunci: tulang khinzir, petrol, produk utama pirolitik, penjerapan karbon teraktif, kromatografi gas-spektrometri jisim

\begin{abstract}
Introduction
Arson is a crime that occurs when a person deliberately or maliciously uses fire to destroy a property [1]. Though arson is an offense against property, it might include an offense against a person if someone is harmed, killed, or dies because of a feloniously set fire [2]. One of the common technique employed by arsonists is the use of ignitable liquids and fire accelerants to ignite and increase the rate and intensity of a fire. Ignitable liquid refers to any liquid that will readily ignite when exposed to heat whereas a fire accelerant is a substance that is used to increase the rate of burning for materials that do not promptly burn [3]. Hence, ignitable liquids can be also used as accelerants. Petrol is known to be the most dominant type of fire accelerant used and found in fire debris samples due to its ease in availability and rapid ignitability [3-5]. The use of petrol has also been associated with human intoxication and death whereby cases of it being ingested and injected with criminal intent either accidentally or intentionally had been reported [6].
\end{abstract}

Presently, the lack of knowledge pertaining to the pyrolytic key indicators of human remains in the presence of interferences, such as petrol, is alarming. Pyrolytic products refer to volatile compounds that are produced during the process of pyrolysis. Pyrolysis is a process, by which a solid or a liquid undergoes degradation of its chemicals into smaller volatile compounds under heat, without interacting with oxygen or any other oxidants, that is necessary for almost all solids or liquids to burn [7]. If human remains are present in a fire scene, the potential pyrolytic key indicators of human remains which are a homologous series of $n$-alkanes, $n$-alkenes, $n$-aldehydes, aromatics and nitrile compounds may be hidden due to the presence of interfering products [8-10]. Interfering products are a set of products detected in a sample that interferes with the proper identification of pyrolytic compounds of the target sample [7]. Petrol can be one of the potential interferences in the identification of human pyrolytic key indicators in a fire.

Although in depth work looking into the pyrolytic key indicators of human remains in the presence of petrol is still novice, previous studies focusing both on the pyrolytic key indicators of petrol and human tissues, individually, have been conducted, the former more detailed than the latter. Generally, pyrolytic data of human samples fall in the range of $n$-alkanes, $n$-alkenes, $n$-aldehydes, aromatics and nitrile compounds [8, 9, 11, 12]. A latest study conducted by DeHaan [13] proved that a homologous series of $\mathrm{C}_{5}-\mathrm{C}_{9} n$-aldehydes serves as dominant pyrolytic key indicators of human samples because these compounds are not produced as major species in the pyrolysis of common household items such as carpet, wood products, and upholstery [13]. However, there are inconsistencies in the presence of $n$-aldehydes from the human pyrolytic model. Although DeHaan et al. [8, 13] and Gabriel et al. [12] detected these compounds in their studies, Purevsuren et al. [14], Agu [11] and Gabriel [9] did not detect any $n$-aldehydes in their pyrolytic work. The absence and presence of $n$-aldehydes were identified due to the differences in temperature, exposure durations and experimental methodology [9]. The inconsistencies in the literature should be addressed to validate the robustness of these pyrolytic key indicators of human tissue, particularly in the presence of interferences.

While the pyrolytic key indicators of human tissues are still being studied, those of petrol have been made known and are readily available across a range of studies [15-19]. A standard test method has also been made available via the American Society of Testing and Materials (ASTM) E1618-06, whom provided the pyrolytic key indicators of petrol to be of alkanes, aromatics such as $\mathrm{C}_{3}-\mathrm{C}_{5}$ alkyl benzenes, naphthalenes and indane together with distinctive chromatographic patterns expected when petrol is analysed [20].

This research is crucial for situations where human remains are not suspected to be present or have been devoured by the fire in the presence of petrol [9]. Bones can often be mistaken as sticks as they discolour to a yellowishbrownish-blackened hue due to environmental factors, including heat and exposure to chemicals [21]. The help of Deoxyribonucleic acid (DNA) fingerprinting that usually aids in the identification of individuals, fails in some cases because of the denaturation of DNA when exposed to high temperatures [22]. Unsuspected fire samples that resemble charred fragments collected from fire debris could potentially contain human tissues that have been burnt with petrol. This research was conducted to determine the pyrolytic key indicators of porcine tissue burnt in the 
presence of petrol under outdoor conditions in order to address the former. Porcine tissue was chosen in this study because it has been proven to be a good representative of human tissue as suggested by various researchers $[8,9,11-13]$ whom have determined clear similarities with no qualitative distinction between the pyrolytic products produced across these tissues in their respective work. Through this research, forensic scientists can be made aware of the chromatographic patterns that signifies the presence of human remains burned in the presence of petrol in fire debris samples [9].

\section{Standard test mixture}

\section{Materials and Method}

12 high purity compounds; benzene, ethylbenzene, butylbenzene, toluene, octane, $p$-xylene, propylbenzene, decane, tridecane, tetradecane, pentadecane and dodecane were prepared in $1 \mathrm{mg} / \mathrm{mL}$ standard solution (Sigma Aldrich, UK) and placed into six GC vials ( $2 \mathrm{~mL}$, Fisher Scientific). The contents of all six GC vials (Fisher Scientific) were then injected into the GC-MS (Shimadzu, UK) and identified using the mass-to-charge ratio $(\mathrm{m} / \mathrm{z}$ ) values compared against the National Institute of Standards and Technology (NIST) (NIST/EPA/NIH Mass Spectral Library).

\section{Standard of unleaded RON95 petrol}

$1.0 \mu \mathrm{L} / \mathrm{mL}$ of RON95 petrol in pentane was injected into the GC-MS. The identification of pyrolytic key indicators of petrol was executed as recommended by ASTM E1618-06 [20]. The total ion chromatogram (TIC) produced was analysed based on the retention times and $\mathrm{m} / \mathrm{z}$ values. Each peak was identified by matching the data against the NIST (NIST/EPA/NIH Mass Spectral Library) and standard test mixture.

\section{GC-MS parameters}

$1.0 \mu \mathrm{L}$ of sample containing desorbed activated carbon tablet (ACT) in pentane was introduced through a split injector with a split ratio of 20:1 at injector temperature of $250{ }^{\circ} \mathrm{C}$ using an auto-sampler. A 128-0122 DB-1MS column $(22 \mathrm{~mm}$ length $\times 0.2 \mathrm{~mm}$ inner diameter $\times 0.33 \mu \mathrm{m}$ film thickness) (Crawford Scientific, UK) was used in this experiment. Helium carrier gas was maintained at a flow rate of $32.7 \mathrm{~mL} / \mathrm{min}$ in the oven. The initial oven temperature was held at $40{ }^{\circ} \mathrm{C}$ for 5 minutes, then ramped to $280{ }^{\circ} \mathrm{C}$ at a rate of $15{ }^{\circ} \mathrm{C} / \mathrm{min}$ and held for 2 minutes. The temperature of the detector was also maintained at $250{ }^{\circ} \mathrm{C}$. Data collected from the GC-MS were analysed based on their retention times and $\mathrm{m} / \mathrm{z}$ values matched against NIST library, standard test mixtures and standard petrol.

\section{Preliminary study: Control sample}

One aluminium tin can was sealed with a lid containing an ACT, which was hooked to a paper clip held by a magnet on the lid and was incubated in an oven for 16 hours at $80{ }^{\circ} \mathrm{C}$ according to guidelines from the American Society for Testing and Materials (ASTM) E1412-07 2012 [23]. After the incubation process, the ACT was removed and placed into a GC vial (Fisher Scientific) and desorbed with $1 \mathrm{~mL}$ of pentane. The GC vial containing the desorbed activated carbon in pentane was then introduced into the GC-MS. This process was repeated three times. An ACT was placed into a GC vial (Fisher Scientific) containing $1 \mathrm{~mL}$ of pentane and was introduced into GC-MS. The entire process was repeated three times. Both control samples were conducted to identify any interfering compounds that could rise from these two sources during the interpretation of GC-MS data of porcine bone burnt in the presence of petrol.

\section{Optimization of volume and post-deprivation sampling times for petrol}

Six replicates of $15 \mathrm{~mL}$ petrol samples were poured into individual $125 \mathrm{~mL}$ aluminium tin cans respectively. Each sample was allowed to burn for 1 minute. Ten seconds before the 1 minute mark, an empty lid was placed over the tin can to extinguish the flame via oxygen deprivation. Out of six replicates, three were allowed to cool for 3 minutes post-deprivation, whereas another three replicates were allowed to cool for 4 minutes post-deprivation. Post-deprivation sampling time refers to the time the sample was left to cool after extinguishment before being sealed by a lid containing ACT. Then, the empty lid was removed and sealed with another lid containing an ACT and was incubated in an oven for 16 hours at $80{ }^{\circ} \mathrm{C}$. After the incubation process, the ACT was removed and placed into a GC vial (Fisher Scientific) containing $1 \mathrm{~mL}$ of pentane and was introduced into the GC-MS. The entire process was then repeated with six $30 \mathrm{~mL}$ of petrol samples that were burnt for 2 minutes and were allowed to cool 
for 3 minutes and 4 minutes, post-deprivation. Both volume and post-deprivation sampling times were tested to observe the number of pyrolytic products generated and to determine the parameters that generated optimal chromatographic output.

\section{Sample preparation}

Fresh porcine femur bones were purchased from the Kajang Wet Market, Selangor, Malaysia. The bones were labelled according to the date acquired and stored in a laboratory freezer at $-21^{\circ} \mathrm{C}$. Before cutting, the bones were defrosted at room temperature for 30 - 40 minutes. The epiphyses of each bone were removed using a bench vice and a hacksaw. Scissors and tweezers were used to get rid of the remaining soft tissues on the bone. Then, the diaphysis was cut into $25 \mathrm{~g} \pm 1.5 \mathrm{~g}$, a recommended size, to be the best weight to generate optimum pyrolysis products [9]. Then, the bone fragment was placed into $125 \mathrm{~mL}$ aluminium tin can. $30 \mathrm{~mL}$ of unleaded RON95 petrol, purchased from the Shell Petroleum Company Ltd Malaysia was then added onto the bone. The entire process was repeated until twelve sets of $25 \mathrm{~g} \pm 1.5 \mathrm{~g}$ of bone samples with $30 \mathrm{~mL}$ of petrol were obtained.

\section{Pyrolysis process}

The outdoor burning experiment was set up at the Forensic Science Simulation Site, Universiti Kebangsaan Malaysia (UKM), Selangor, Malaysia. A retort stand was placed on a flat ground and the tin can without the lid containing the sample was placed on a tripod stand during the burning process. The sample was heated using a Bunsen burner which was placed under the tin can and connected to a Liquefied Petroleum Gas (LPG) tank by using a $1.5 \mathrm{~m}$ length of gas hose and the flow of gas was controlled by a valve. A k-thermocouple connected to a digital thermometer model 51 II (Fluke) was used to monitor the temperature of the sample during pyrolysis. Six samples were allowed to continuously burn and self-extinguish and another six samples were not allowed to selfextinguish.

For the latter six samples, reaching the auto-ignition stage of the samples, the flames were extinguished using an empty lid when the size of the flames reduces to burning within the tin. These two methodologies were employed to compare and contrast the presence and type of pyrolysis products detected when the samples were purposely extinguished versus those that self-extinguished. The covered tin can contain the burnt sample was then left to cool for 4 minutes post-deprivation. The empty lid was then replaced with another lid containing an ACT, which was hooked to a paper clip held by a magnet on the lid. The tin was sealed shut and incubated in an oven for 16 hours at $80^{\circ} \mathrm{C}$ (ASTM E1412-07) [23]. After the incubation process, the ACT was removed and placed into a GC vial (Fisher Scientific) containing $0.5 \mathrm{mg} / \mathrm{mL}$ of tetrachloroethylene (internal standard) and desorbed with $1 \mathrm{~mL}$ of pentane. The GC vial containing the desorbed activated carbon in pentane was then introduced into the GC-MS.

\section{Control sample for empty aluminium tin and ACT}

\section{Results and Discussion}

The analysis of the aluminium tin can and ACT did not produce any volatile organic compounds, suggesting no possible interferences from these two sources during the analysis of the target compounds from burnt porcine bones in the presence of petrol.

\section{Optimization of volume and post-deprivation sampling time for petrol}

When $15 \mathrm{~mL}$ of petrol samples were burnt, the range of time the flames took to self-extinguish were between 1.33 minutes to 1.53 minutes. Hence, the burning time was shortened to 1 minute for the generation of detectable pyrolysis products. Post-deprivation sampling times of 3 minutes and 4 minutes were tested because the ranges of time taken for the headspace of the samples to cool to room temperature were between 3 minutes and 4.5 minutes. 
The results of the repetitive analysis of $15 \mathrm{~mL}$ of burnt petrol that were cooled for 3 minutes post-deprivation are tabulated in Table 1 and a representative of total ion chromatogram (TIC) is labelled and illustrated in Figure 1. A range of $\mathrm{C}_{2}$-alkylbenzenes and $\mathrm{C}_{3}$-alkylbenzenes were detected. Toluene was also present. Indane and $\mathrm{C}_{4^{-}}$ alkylbenzenes such as tetramethylbenzenes, which were the pyrolytic key indicators of petrol according to ASTM E1618-06 were not detected. In terms of consistently appearing products, toluene, $m$-xylene, $p$-xylene, 1,3,5trimethylbenzene, 1,2,4-trimethylbenzene and 1,2,3-trimethylbenzene were relatively consistent in triplicate analysis. The maximum temperature attained during the heating process in the headspace above the samples were recorded to be in the range of $190^{\circ} \mathrm{C}$ to $314^{\circ} \mathrm{C}$ as illustrated in Figure 2 .

Table 1. Eight compounds identified based on the $\mathrm{m} / z$ values and retention times for three $15 \mathrm{~mL}$ of burnt petrol samples at 3 minutes post-deprivation sampling time

\begin{tabular}{lcllccc}
\hline \multirow{2}{*}{ No. } & Retention & \multirow{2}{*}{ Time(min) } & Compound & \multicolumn{3}{c}{ Replicates } \\
\cline { 4 - 6 } & 3.385 & toluene & 1 & $\mathbf{2}$ & $\mathbf{3}$ \\
\hline 1. & 6.063 & ethylbenzene & ND & ND & $\sqrt{ }$ \\
2. & 6.296 & $m$-xylene & $\sqrt{ }$ & $\sqrt{ }$ & $\sqrt{ }$ \\
3. & 6.807 & $p$-xylene & $\sqrt{ }$ & $\sqrt{ }$ & $\sqrt{ }$ \\
4. & 8.192 & 1-ethyl-3-methylbenzene & ND & ND & $\sqrt{ }$ \\
5. & 8.325 & 1,3,5-trimethylbenzene & $\sqrt{ }$ & $\sqrt{ }$ & $\sqrt{ }$ \\
6. & 8.713 & 1,2,4-trimethylbenzene & $\sqrt{ }$ & $\sqrt{ }$ & $\sqrt{ }$ \\
7. & 9.112 & 1,2,3-trimethylbenzene & $\sqrt{ }$ & $\sqrt{ }$ & $\sqrt{ }$ \\
8. & & & & & &
\end{tabular}

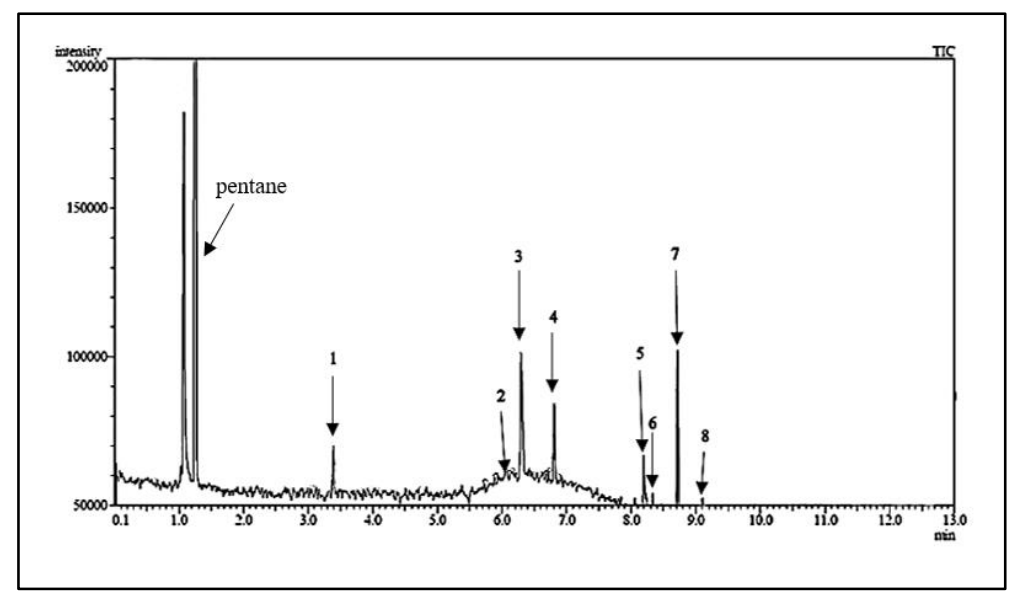

Figure 1. A representative of TIC of a $15 \mathrm{~mL}$ of burnt petrol sample at 3 minutes post-deprivation sampling time (replicate 3) 


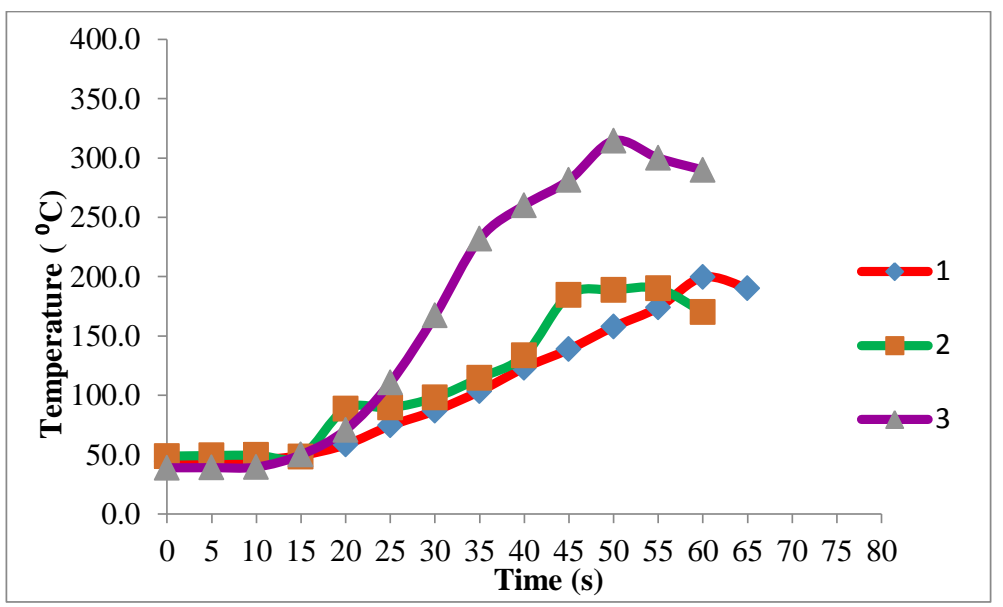

Figure 2. Overlay of three-time temperature profiles of $15 \mathrm{~mL}$ of burnt petrol samples at 3 minutes postdeprivation sampling time

The derived products for the $15 \mathrm{~mL}$ of burnt petrol samples, cooled for 4 minutes post-deprivation are tabulated in Table 2 and a representative of the total ion chromatogram (TIC) is labelled and illustrated in Figure $3.15 \mathrm{~mL}$ of burnt petrol samples that were cooled for 4 minutes post-deprivation produced a range of $\mathrm{C}_{2}$-alkylbenzenes, $\mathrm{C}_{3^{-}}$ alkylbenzenes and $\mathrm{C}_{4}$-alkylbenzenes. Toluene and indane were generated too. In terms of consistently appearing products, toluene, $m$-xylene, $p$-xylene, 1-ethyl-3-methylbenzene, 1,3,5- trimethylbenzene, 1,2,4-trimethylbenzene and 1,2,3-trimethylbenzene were relatively consistent across the three replicates. The maximum temperature attained during the heating process in the headspace above the samples were recorded to be in the range of $207^{\circ} \mathrm{C}$ to $374^{\circ} \mathrm{C}$ as illustrated in Figure 4.

Table 2. Thirteen compounds identified based on the $m / z$ values and retention times for three $15 \mathrm{~mL}$ of burnt petrol samples at 4 minutes post-deprivation sampling time

\begin{tabular}{|c|c|c|c|c|c|}
\hline \multirow{2}{*}{ No. } & \multirow{2}{*}{$\begin{array}{c}\text { Retention } \\
\text { Time (min) }\end{array}$} & \multirow{2}{*}{ Compound } & \multicolumn{3}{|c|}{ Replicates } \\
\hline & & & 1 & 2 & 3 \\
\hline 1. & 3.385 & toluene & $\sqrt{ }$ & $\sqrt{ }$ & $\sqrt{ }$ \\
\hline 2. & 6.063 & ethylbenzene & $\sqrt{ }$ & ND & $\sqrt{ }$ \\
\hline 3. & 6.296 & $m$-xylene & $\sqrt{ }$ & $\sqrt{ }$ & $\sqrt{ }$ \\
\hline 4. & 6.807 & $p$-xylene & $\sqrt{ }$ & $\sqrt{ }$ & $\sqrt{ }$ \\
\hline 5. & 8.053 & $n$-propylbenzene & ND & ND & $\sqrt{ }$ \\
\hline 6. & 8.192 & 1-ethyl-3-methylbenzene & $\sqrt{ }$ & $\sqrt{ }$ & $\sqrt{ }$ \\
\hline 7. & 8.325 & 1,3,5-trimethylbenzene & $\sqrt{ }$ & $\sqrt{ }$ & $\sqrt{ }$ \\
\hline 8. & 8.469 & 1-ethyl-2-methylbenzene & $\sqrt{ }$ & ND & $\sqrt{ }$ \\
\hline 9. & 8.713 & 1,2,4-trimethylbenzene & $\sqrt{ }$ & $\sqrt{ }$ & $\sqrt{ }$ \\
\hline 10. & 9.112 & 1,2,3-trimethylbenzene & $\sqrt{ }$ & $\sqrt{ }$ & $\sqrt{ }$ \\
\hline 11. & 9.259 & indane & ND & ND & $\sqrt{ }$ \\
\hline 12. & 10.395 & 1,2,4,5-tetramethylbenzene & $\sqrt{ }$ & ND & $\sqrt{ }$ \\
\hline 13. & 10.435 & 1,2,3,5-tetramethylbenzene & $\sqrt{ }$ & $\mathrm{ND}$ & $\sqrt{ }$ \\
\hline
\end{tabular}




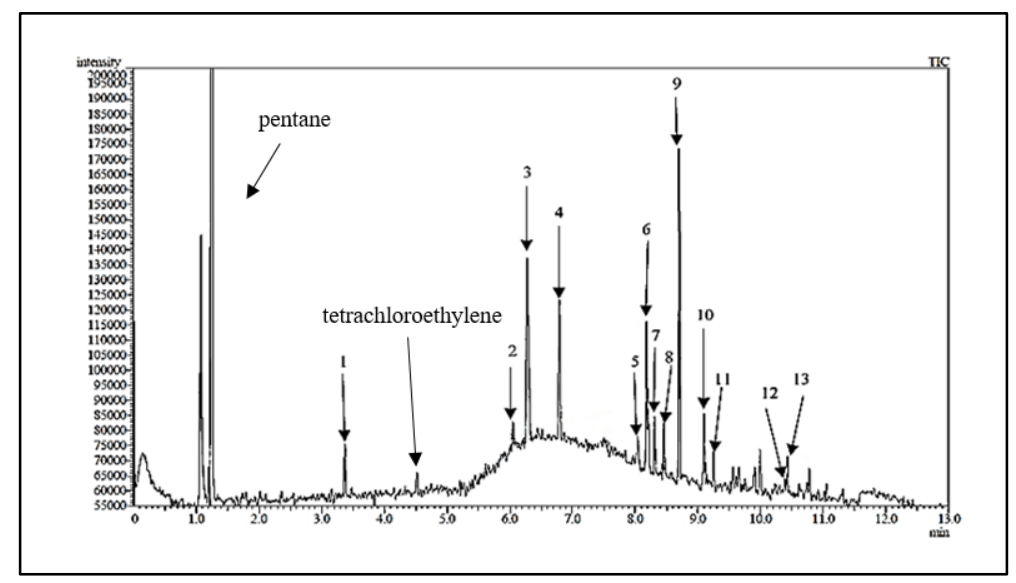

Figure 3. A representative of TIC of a $15 \mathrm{~mL}$ of burnt petrol sample cooled for 4 minutes post-deprivation sampling time (replicate 3)

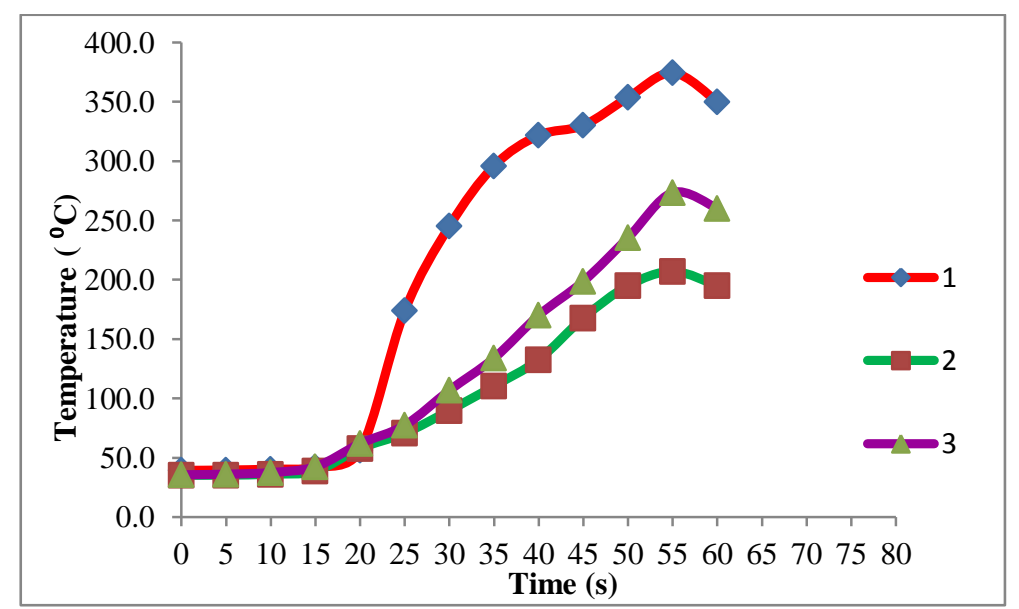

Figure 4. Overlay of three-time temperature profiles of $15 \mathrm{~mL}$ of burnt petrol samples at 4 minutes postdeprivation sampling time

When $30 \mathrm{~mL}$ of petrol samples were burned, the range of time it took to self-extinguish were between 2.08 minutes and 2.87 minutes. Hence, the burning time was shortened to 2 minute for the generation of detectable pyrolysis products. Post-deprivation sampling times of 3 minutes and 4 minutes were tested because the ranges of time taken for the headspace of the samples to cool to room temperature were between 3.8 minutes and 4.2 minutes.

The results of the repetitive analysis of $30 \mathrm{~mL}$ of burnt petrol samples cooled for 3 minutes post-deprivation are tabulated in Table 3 and a representative of total ion chromatogram (TIC) is labelled and illustrated in Figure 5. $30 \mathrm{~mL}$ of petrol samples cooled for 3 minutes post-deprivation produced a range of $\mathrm{C}_{2}$-alkylbenzenes, $\mathrm{C}_{3}$ alkylbenzenes and $\mathrm{C}_{4}$-alkylbenzenes. Toluene and indane were also detected. In terms of consistently appearing products, $\mathrm{C}_{2}$-alkylbenzenes, $\mathrm{C}_{3}$-alkylbenzenes and $\mathrm{C}_{4}$-alkylbenzenes were relatively consistent across the three replicates. The maximum temperature attained during the heating process in the headspace above the samples were recorded to be in the range of $224^{\circ} \mathrm{C}$ to $356^{\circ} \mathrm{C}$ as illustrated in Figure 6. 
Gabriel et al: PYROLYTIC KEY INDICATORS OF BURNT PORCINE TISSUE IN THE PRESENCE OF PETROL UNDER OUTDOOR CONDITIONS

Table 3. Eighteen compounds identified based on the $\mathrm{m} / \mathrm{z}$ values and retention times for three $30 \mathrm{~mL}$ of burnt petrol samples at 3 minutes post-deprivation sampling time

\begin{tabular}{|c|c|c|c|c|c|}
\hline \multirow{2}{*}{ No. } & \multirow{2}{*}{$\begin{array}{l}\text { Retention } \\
\text { Time (min) }\end{array}$} & \multirow{2}{*}{ Compound } & \multicolumn{3}{|c|}{ Replicates } \\
\hline & & & 1 & 2 & 3 \\
\hline 1. & 3.385 & toluene & $\sqrt{ }$ & ND & $\sqrt{ }$ \\
\hline 2. & 6.063 & ethylbenzene & ND & ND & $\sqrt{ }$ \\
\hline 3. & 6.296 & $m$-xylene & $\sqrt{ }$ & $\sqrt{ }$ & $\sqrt{ }$ \\
\hline 4. & 6.807 & $p$-xylene & $\sqrt{ }$ & $\sqrt{ }$ & $\sqrt{ }$ \\
\hline 5. & 8.053 & $n$-propylbenzene & $\sqrt{ }$ & $\sqrt{ }$ & $\sqrt{ }$ \\
\hline 6. & 8.192 & 1-ethyl-3-methylbenzene & $\sqrt{ }$ & $\sqrt{ }$ & $\sqrt{ }$ \\
\hline 7. & 8.325 & 1,3,5-trimethylbenzene & $\sqrt{ }$ & $\sqrt{ }$ & $\sqrt{ }$ \\
\hline 8. & 8.469 & 1-ethyl-2-methylbenzene & $\sqrt{ }$ & $\sqrt{ }$ & $\sqrt{ }$ \\
\hline 9. & 8.713 & 1,2,4-trimethylbenzene & $\sqrt{ }$ & $\sqrt{ }$ & $\sqrt{ }$ \\
\hline 10. & 9.112 & 1,2,3-trimethylbenzene & $\sqrt{ }$ & $\sqrt{ }$ & $\sqrt{ }$ \\
\hline 11. & 9.259 & indane & $\sqrt{ }$ & ND & $\sqrt{ }$ \\
\hline 12. & 9.567 & 1-methyl-4-propylbenzene & $\sqrt{ }$ & $\sqrt{ }$ & $\sqrt{ }$ \\
\hline 13. & 9.625 & 1-methyl-2-propylbenzene & $\sqrt{ }$ & ND & ND \\
\hline 14. & 9.667 & 2-ethyl-1,4-dimethylbenzene & $\sqrt{ }$ & ND & ND \\
\hline 15. & 9.908 & 1-methyl-4-(1-methylethyl)benzene & $\sqrt{ }$ & $\sqrt{ }$ & $\sqrt{ }$ \\
\hline 16. & 10.000 & 1-methyl-2-(1-methylethyl)benzene & $\sqrt{ }$ & $\sqrt{ }$ & $\sqrt{ }$ \\
\hline 17. & 10.400 & 1,2,4,5-tetramethylbenzene & ND & $\sqrt{ }$ & $\sqrt{ }$ \\
\hline 18. & 10.435 & 1,2,3,5-tetramethylbenzene & ND & $\sqrt{ }$ & $\sqrt{ }$ \\
\hline
\end{tabular}

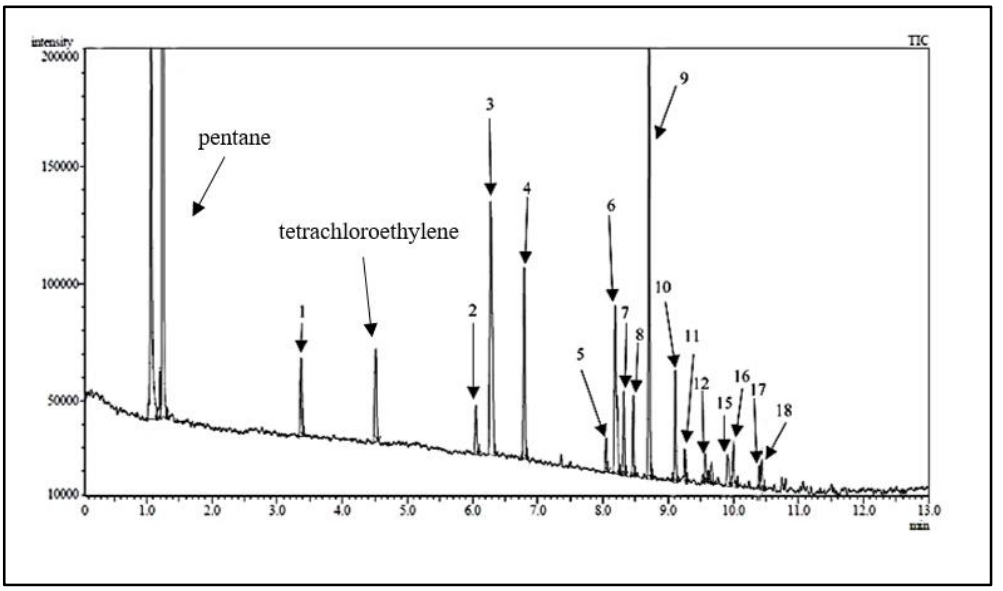

Figure 5. A representative of TIC of a $30 \mathrm{~mL}$ of burnt petrol sample at 3 minutes post-deprivation sampling time (replicate 3) 


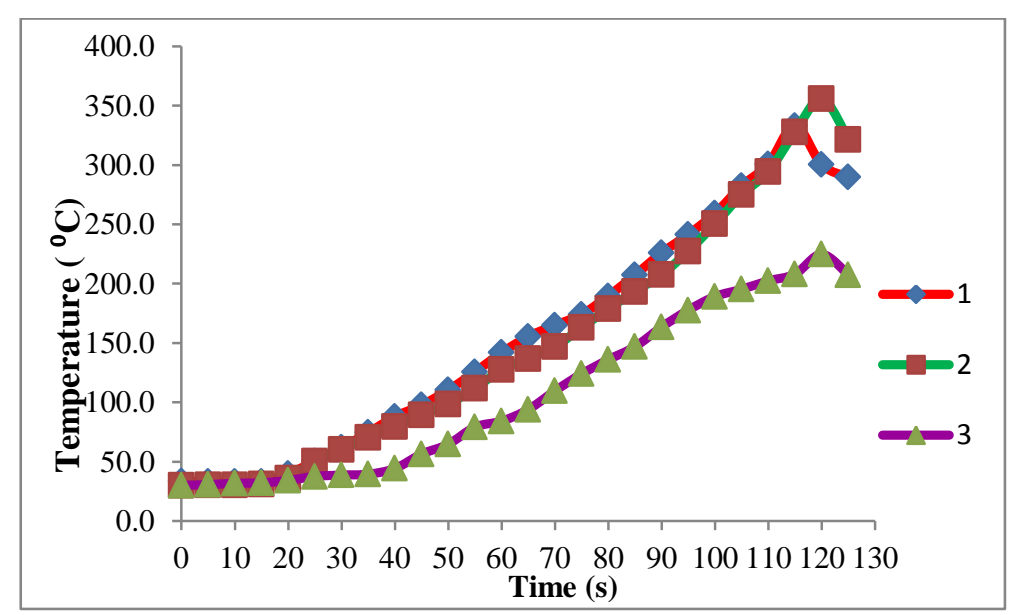

Figure 6. Overlay of three-time temperature profiles of $30 \mathrm{~mL}$ of burnt petrol samples at 3 minutes postdeprivation sampling time

The results of the derived products of $30 \mathrm{~mL}$ of burnt petrol samples cooled for 4 minutes post-deprivation are tabulated in Table 4 and a representative of total ion chromatogram (TIC) is labelled and illustrated in Figure 7. All the three samples generated consistent presence of toluene, indane and most of $\mathrm{C}_{2}$-alkylbenzenes, $\mathrm{C}_{3}$-alkylbenzenes and $\mathrm{C}_{4}$-alkylbenzenes. Even though across the replicates, the rest of the products appeared with relatively good qualitative reproducibility, 2,3-dimethylhexane (replicate 2) and 1-ethyl-4-methylbenzene (replicate 3) were only detected once out of three replicates and these two compounds were only present in this analysis. This is most likely due to the fire dynamics experienced by the replicates during the burning process [7]. Replicate 3 experienced the lowest temperature ranges in comparison to the other two replicates. The lower temperatures could have shielded 1-ethyl-4-methylbenzene from being consumed by the higher levels of heat, and flames, as experienced by replicate 1 and replicate 2 as higher temperatures are known to cause further decomposition of smaller pyrolytic compounds [11,12]. On the other hand, even though replicate 2 experienced higher temperature ranges in comparison to replicate 1 and replicate 3,2,3-dimethylhexane was still detected. In this case, it could be down to the need of higher temperature ranges to volatilise 2,3-dimethylhexane from the petrol sample. Similar outcomes were noted in the literature whereby higher molecular weight compounds were found to require higher temperatures in order to resolve $[7,12,24]$. The maximum temperature attained during the heating process in the headspace above the samples were recorded to be in the range of $180^{\circ} \mathrm{C}$ to $315^{\circ} \mathrm{C}$ as illustrated in Figure 8 .

Table 4. Twenty compounds identified based on the $\mathrm{m} / \mathrm{z}$ values and retention times for three $30 \mathrm{~mL}$ of burnt petrol samples at 4 minutes post-deprivation sampling time

\begin{tabular}{lllccc}
\hline \multirow{2}{*}{ No. } & Retention & \multirow{2}{*}{ Time $(\mathbf{m i n})$} & Compound & \multicolumn{3}{c}{ Replicates } \\
\cline { 4 - 6 } & & $\mathbf{1}$ & $\mathbf{2}$ & $\mathbf{3}$ \\
\hline 1. & 3.385 & toluene & $\sqrt{ }$ & $\sqrt{ }$ & $\sqrt{ }$ \\
2. & 3.875 & 2,3-dimethylhexane & $\mathrm{ND}$ & $\sqrt{ }$ & $\mathrm{ND}$ \\
3. & 6.063 & ethylbenzene & $\sqrt{ }$ & $\sqrt{ }$ & $\sqrt{ }$ \\
4. & 6.296 & $m$-xylene & $\sqrt{ }$ & $\sqrt{ }$ & $\sqrt{ }$ \\
5. & 6.807 & p-xylene & $\sqrt{ }$ & $\sqrt{ }$ & $\sqrt{ }$ \\
6. & 8.053 & $n$-propylbenzene & $\sqrt{ }$ & $\sqrt{ }$ & $\sqrt{ }$ \\
7. & 8.192 & 1-ethyl-3-methylbenzene & $\sqrt{ }$ & $\sqrt{ }$ & $\sqrt{ }$ \\
8. & 8.225 & 1-ethyl-4-methylbenzene & ND & ND & $\sqrt{ }$ \\
\hline
\end{tabular}


Gabriel et al: PYROLYTIC KEY INDICATORS OF BURNT PORCINE TISSUE IN THE PRESENCE OF PETROL UNDER OUTDOOR CONDITIONS

Table 4 (cont'd). Twenty compounds identified based on the $m / z$ values and retention times for three $30 \mathrm{~mL}$ of burnt petrol samples at 4 minutes post-deprivation sampling time

\begin{tabular}{llllll}
\hline \multirow{2}{*}{ No. } & Retention & \multirow{2}{*}{ Time (min) } & Compound & \multicolumn{3}{c}{ Replicates } \\
\cline { 4 - 6 } & & $\mathbf{1}$ & $\mathbf{2}$ & $\mathbf{3}$ \\
\hline 9. & 8.325 & 1,3,5-trimethylbenzene & $\sqrt{ }$ & $\sqrt{ }$ & $\sqrt{ }$ \\
10. & 8.469 & 1-ethyl-2-methylbenzene & $\sqrt{ }$ & $\sqrt{ }$ & $\sqrt{ }$ \\
11. & 8.713 & 1,2,4-trimethylbenzene & $\sqrt{ }$ & $\sqrt{ }$ & $\sqrt{ }$ \\
12. & 9.112 & 1,2,3-trimethylbenzene & $\sqrt{ }$ & $\sqrt{ }$ & $\sqrt{ }$ \\
13. & 9.259 & indane & $\sqrt{ }$ & $\sqrt{ }$ & $\sqrt{ }$ \\
14. & 9.567 & 1-methyl-4-propylbenzene & $\sqrt{ }$ & $\sqrt{ }$ & $\sqrt{ }$ \\
15. & 9.625 & 1-methyl-2-propylbenzene & ND & $\sqrt{ }$ & $\sqrt{ }$ \\
16. & 9.667 & 2-ethyl-1,4-dimethylbenzene & $\sqrt{ }$ & $\sqrt{ }$ & $\sqrt{ }$ \\
17. & 9.908 & 1-methyl-4-(1-methylethyl)benzene & $\sqrt{ }$ & $\sqrt{ }$ & $\sqrt{ }$ \\
18. & 10.000 & 1-methyl-2-(1-methylethyl)benzene & $\sqrt{ }$ & $\sqrt{ }$ & ND \\
19. & 10.400 & 1,2,4,5-tetramethylbenzene & $\sqrt{ }$ & ND & $\sqrt{ }$ \\
20. & 10.435 & 1,2,3,5-tetramethylbenzene & $\sqrt{ }$ & ND & $\sqrt{ }$ \\
\hline
\end{tabular}

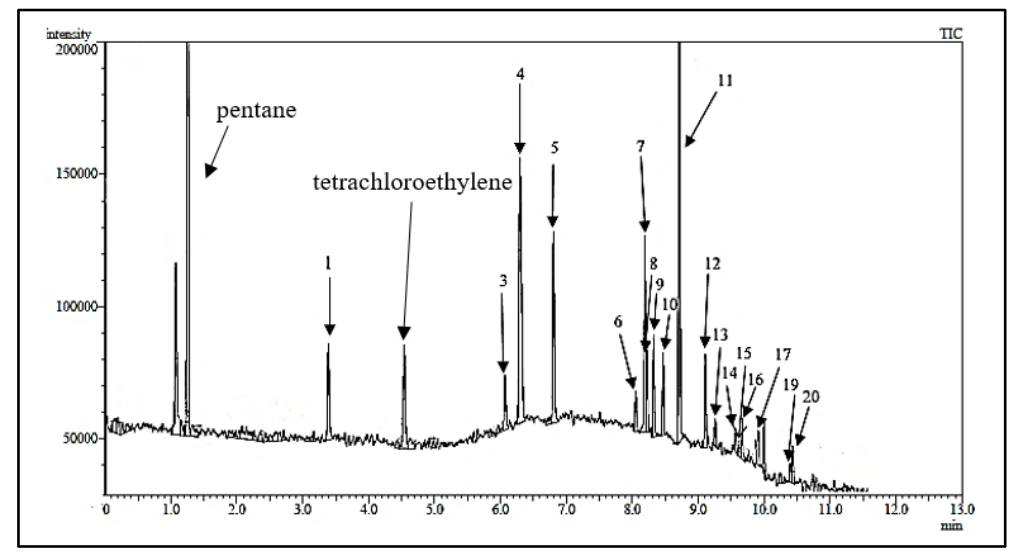

Figure 7. A representative of TIC of a $30 \mathrm{~mL}$ of burnt petrol sample at 4 minutes post-deprivation sampling time (replicate 3) 


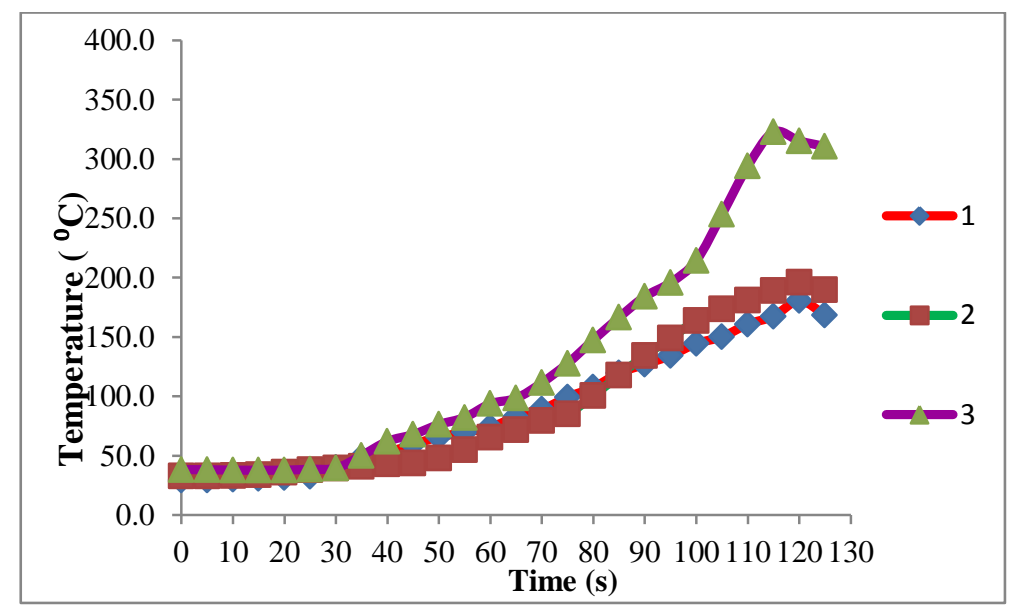

Figure 8. Overlay of three-time temperature profiles of $30 \mathrm{~mL}$ of burnt petrol samples at 4 minutes postdeprivation sampling time

$30 \mathrm{~mL}$ of burnt petrol samples, as tabulated in Table 3 and Table 4 respectively produced a higher number of pyrolytic products (18 to 20 compounds) as compared to $15 \mathrm{~mL}$ of petrol samples ( 8 to 13 compounds) as tabulated in Table 1 and Table 2 respectively. This shows that larger volumes of petrol generated considerably more pyrolysis product in comparison to lesser volumes. The number of consistently detected products across the three replicates of sampling for $30 \mathrm{~mL}$ of burnt petrol samples cooled for 4 minutes post-deprivation as tabulated in Table 3 were 14 which is greater in comparison to $30 \mathrm{~mL}$ of burnt petrol samples cooled for 3 minutes postdeprivation as tabulated in Table 4 which were only 11 . Thus, $30 \mathrm{~mL}$ of volume of petrol and 4 minutes postdeprivation sampling time were applied in the next stage of the experiment.

\section{Porcine bone burnt in the presence of petrol}

Pyrolysis processes have been applied by using two methods for this research. In the first method, the sample was allowed to continuously burn till it reached auto-ignition and the flames were allowed to self-extinguish. In the second method, upon auto-ignition, the flames were extinguished by placing an empty lid over the tin when the size of the flame reduces to burning within the tin. The results obtained across all the six replicates over both methods are tabulated across Table 5 and Table 6 , respectively. A representative of total ion chromatogram (TIC) is labelled and illustrated in Figure 9 and Figure 10, respectively.

Across the six replicates for the first method, only toluene was detected as displayed in Table 5. Toluene only appeared in three of the six replicates. Maximum temperatures attained across the headspace above the six replicates varied and were between $315{ }^{\circ} \mathrm{C}$ to $547{ }^{\circ} \mathrm{C}$ with exposure to heat ranging from 2.35 minutes to 4 minutes, as illustrated in Figure 10.

Table 5. One compound identified based on the $m / z$ values and retention time when six samples were allowed to continuously burn upon auto-ignition and self-extinguish

\begin{tabular}{lllllllll}
\hline \multirow{2}{*}{ No. } & $\begin{array}{l}\text { Retention Time } \\
(\mathbf{m i n})\end{array}$ & \multirow{2}{*}{ Compound } & \multicolumn{6}{c}{ Replicates } \\
\cline { 4 - 8 } & & $\mathbf{1}$ & $\mathbf{2}$ & $\mathbf{3}$ & $\mathbf{4}$ & $\mathbf{5}$ & $\mathbf{6}$ \\
\hline 1. & 3.385 & toluene & $\sqrt{ }$ & ND & ND & $\sqrt{ }$ & ND & $\sqrt{ }$ \\
\hline
\end{tabular}




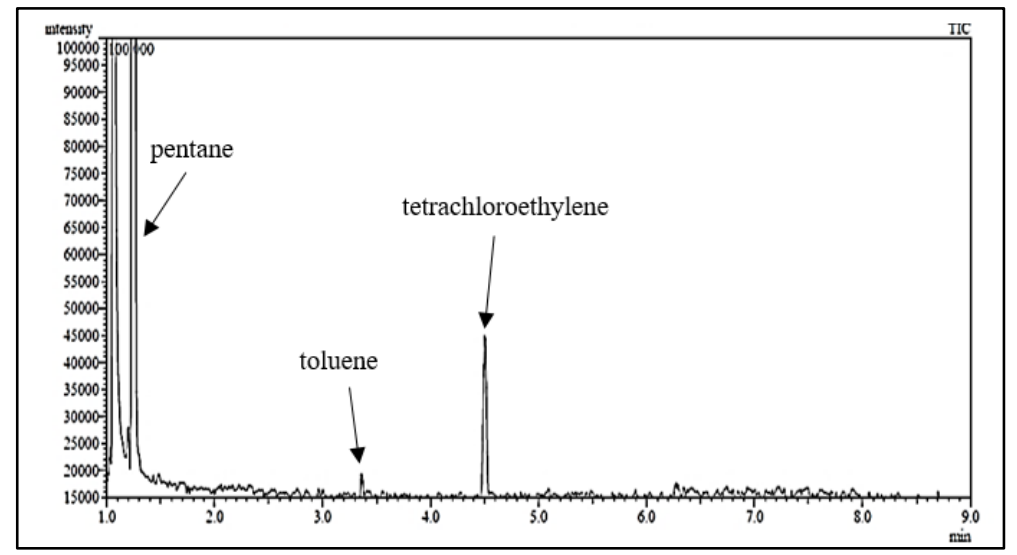

Figure 9. A representative of TIC when the sample was allowed to continuously burn upon auto-ignition and selfextinguish (replicate 4)

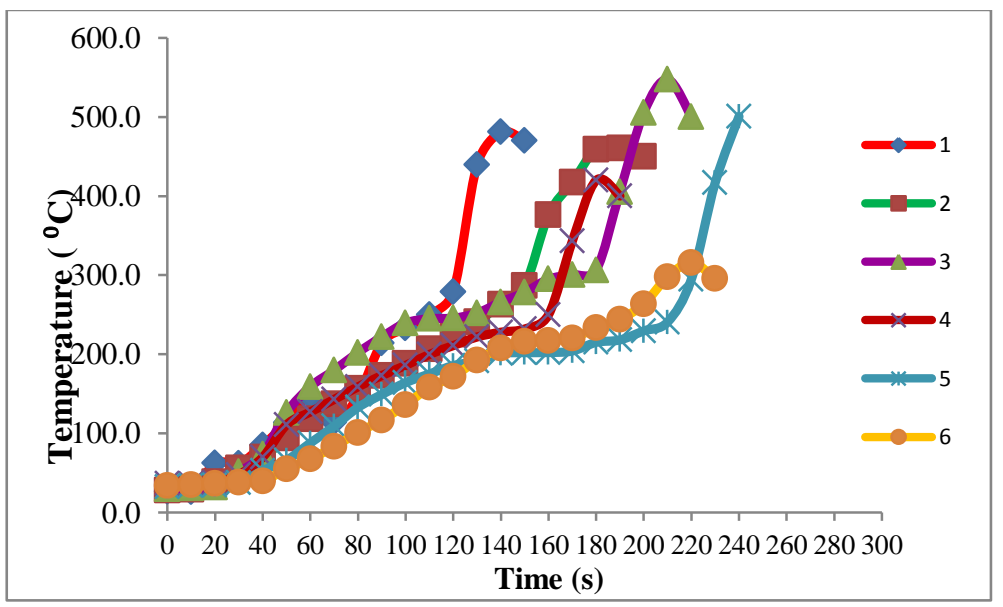

Figure 10. Overlay of six time temperature profiles when the samples were allowed to continuously burn upon auto-ignition and self-extinguish

Meanwhile, across the six replicates for the second method, only 1,2,4,-trimethylbenzene was detected, appearing in four of the six replicates, as displayed in Table 6 . The maximum temperature attained during the heating process in the headspace above the samples were recorded to be in the range of $260^{\circ} \mathrm{C}$ to $580^{\circ} \mathrm{C}$ with the duration of exposure to heat ranging from $2.67-4.17$ minutes as illustrated in Figure 11.

Table 6. One compound identified based on the $\mathrm{m} / \mathrm{z}$ values and retention time when the flames upon auto-ignition were extinguished, when the size of the flames reduce to burning within the tin

\begin{tabular}{lllllllll}
\hline \multirow{2}{*}{ No. } & $\begin{array}{l}\text { Retention Time } \\
(\mathbf{m i n})\end{array}$ & Compound & \multicolumn{6}{c}{ Replicates } \\
\cline { 3 - 7 } & & $\mathbf{1}$ & $\mathbf{2}$ & $\mathbf{3}$ & $\mathbf{4}$ & $\mathbf{5}$ & $\mathbf{6}$ \\
\hline 1. & 8.713 & $1,2,4-$ trimethylbenzene & $\sqrt{ }$ & $\sqrt{ }$ & $\sqrt{ }$ & $\sqrt{ }$ & ND & ND \\
\hline
\end{tabular}




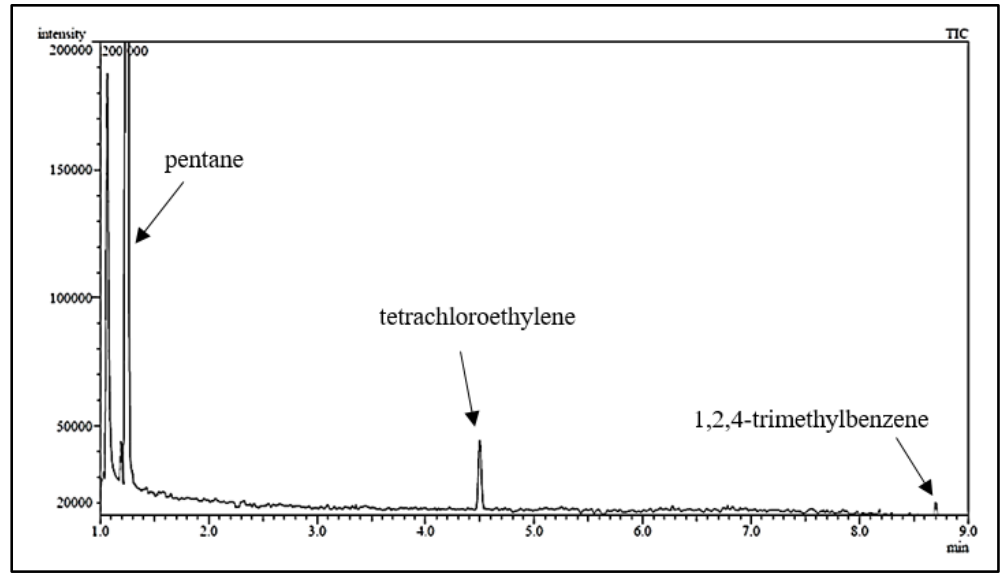

Figure 11. A representative of TIC when the flame auto-ignition was extinguished, when the size of the flame reduces to burning within the tin (replicate 3 )

Good qualitative reproducibility across six replicates were not obtained for toluene and 1,2,4,-trimethylbenzene, respectively due to them being consumed or lost during the burning process [19]. Other petrol compounds as detailed in Table 4 were not detected. This could primarily be due to the extended burning duration of more than 2 minutes for $30 \mathrm{~mL}$ of petrol, in which most of the fuel could have been vaporized or consumed by auto-ignited flames [9]. Besides that, when $30 \mathrm{~mL}$ of petrol samples were burned during the preliminary study, maximum temperatures attained across the headspace of the six replicates were between $180{ }^{\circ} \mathrm{C}$ to $356{ }^{\circ} \mathrm{C}$ (Figure 6 and Figure 8), respectively. However, when petrol was burned together with porcine bones, temperatures exceeded $400{ }^{\circ} \mathrm{C}$ (Figure 10 and Figure 12) for most of the samples in both methods. These higher ranges of temperatures could have induced the thermal decomposition of pyrolysis products generated from petrol $[11,15]$. In the absence of petrol, the maximum temperature attained in Gabriel et al.'s [12] work was $580{ }^{\circ} \mathrm{C}$ at approximately 13 minutes when porcine bones were burnt in an open flame under outdoor conditions. In this work, when petrol was used, the temperature raised to $580^{\circ} \mathrm{C}$ within 3 - 4 minutes. This shows that petrol works as a good accelerant to increase the rate of burning of a material, in this case porcine tissue (in extension, human tissue).

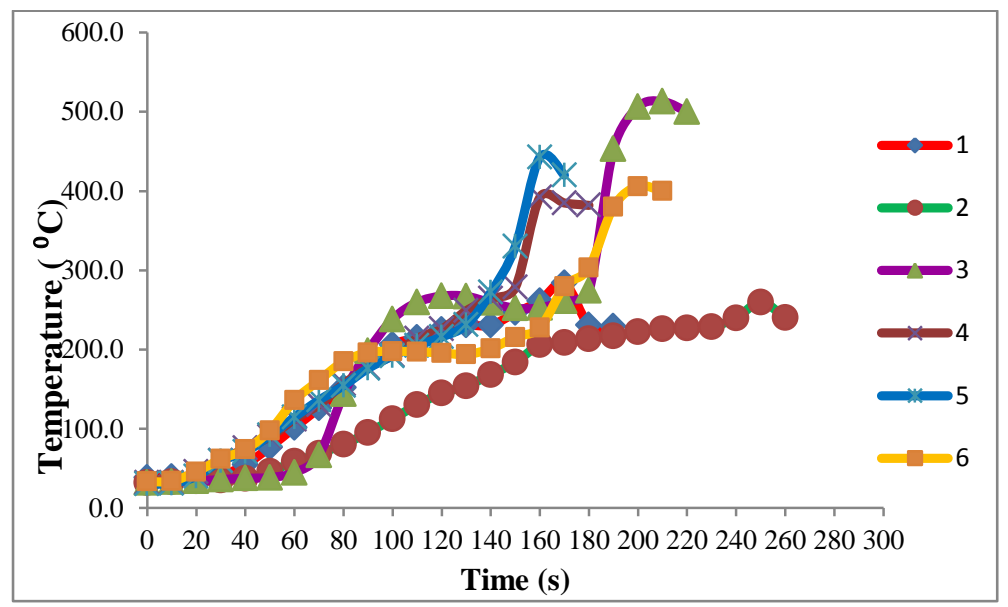

Figure 12. Overlay of six-time temperature profiles when the flames upon auto-ignition were extinguished, when the size of the flames reduce to burning within the tin 


\section{Gabriel et al: PYROLYTIC KEY INDICATORS OF BURNT PORCINE TISSUE IN THE PRESENCE OF PETROL UNDER OUTDOOR CONDITIONS}

Toluene, detected in the first method, is a common compound that can be found from the pyrolysis of petrol as well as from the pyrolysis of porcine bones $[12,15]$. It is not possible to distinguish the origin of toluene as coming from petrol or porcine bones. Moreover, toluene on its own cannot be used as a pyrolytic key indicator of human tissue burnt with petrol because toluene is a common interference product present in most household materials [15]. Whereas, 1,2,4-trimethylbenzene which was obtained from the second method, has been reported to be unique pyrolytic key indicator of petrol [20].

Nonetheless, the pyrolytic key indicators of porcine bone burnt with petrol were not detected across both methods, even though through visual observations, all the replicates of porcine bones burnt with petrol underwent autoignition during the burning process. Bone was noted to experience auto-ignition as the level of petrol within the tin was nearing the fully consumed stage and when the flames had changed focus to within the bone. The auto-ignition events were most likely due to ignition of petrol which could have raised the temperature in the tin, facilitating the auto-ignition of the porcine bones at an early stage [9]. However, the visualised auto-ignition of bones could have also been of petrol that had absorbed itself within the bone marrow and structures of the bone (bone functioning as a wick) [25, 26]. If this occurred, the visualised auto-ignition could be of petrol rather than the bone, explaining the absence of the pyrolytic products from bone.

From another point of view, the absence of pyrolytic products of porcine bones could be due to the short duration of burning. In Gabriel et al.'s [12] work, optimum pyrolysis products were detected when porcine bones were exposed to an open flame burnt under outdoor conditions for approximately 13 minutes. However, in this research, the burning time was only in the range of approximately $3-4$ minutes, the short time duration would not have been sufficient enough for the bone to undergo optimum pyrolysis under outdoor conditions. Burning time was not lengthened to prevent petrol from being fully consumed by the fire. If the burning durations were lengthened, it would not depict a real fire scenario where petrol can still be found in fire debris because; i) the initial heat source would not be present throughout the fire, ii) petrol would have been absorbed into underlying materials such as clothing and wood that serve as a wick $[25,26]$ and iii) some parts of the body that were not exposed directly to the heat or protected from the heat, would contain remnants of petrol residue.

Even though temperatures rose to $580{ }^{\circ} \mathrm{C}$ within a short duration of time, the experimental methodology employed in a study also plays an important role in dictating the generation and detection of volatile compounds of bone. In previous work, DeHaan et al. [8] determined the presence of $n$-aldehydes from the burning of porcine fat in a contained micro furnace at $300{ }^{\circ} \mathrm{C}, 500{ }^{\circ} \mathrm{C}$ and $700{ }^{\circ} \mathrm{C}$ for 10 seconds. The use of a micro furnace in a contained environment facilitates more control on the combustion and pyrolysis process and also prevents any generated products from escaping [9] whereas in this research, porcine bones were burnt in an open flame under outdoor conditions in which many factors such as variation in the concentration of oxygen that is largely controlled by wind conditions, can alter the burning efficiency and prevent a steady supply of flames and heat [27, 28]. Hence, no $n$-aldehydes were detected. Similar outcomes were also suggested in Agu and Gabriel's work [9, 11]. In Gabriel et al.'s [12] work utilising similar environmental conditions as per this study minus the use of petrol, a homologous series of $n$-alkanes, $n$-alkenes, $n$-aldehydes, aromatics and nitrile were detected from auto-ignited bones, that were not present in this study. A plausible explanation here could be down to the source of flames used in both research. In Gabriel et al.'s [12] work, a portable gas canister was used, whereas in this study a LPG gas tank with an adjustable pressure valve was used. Variations in the experimental methodology particularly pressure and ratio of mixed gas supplied during the burning process could have altered the heat transfer rate and burning profiles of bones (auto-ignition versus no auto-ignition). This warrants further investigation as information degrading this is pertinent to the forensic community to understand the effects of different factors to the process of pyrolysis and combustion. Besides experimental methodology, other factors such as the presence of clothing and other materials around the human tissue, humidity and circumstances surrounding death have also been reported to impart a profound effect on the thermal decomposition of human tissues [29-31].

\section{Conclusion}

The pyrolytic key indicators of porcine bones were not detected when burnt together with petrol under the environmental conditions specific to this research. Toluene was detected when porcine bone samples in the 
presence of petrol were allowed to continuously burn upon auto-ignition and self-extinguish. However, the presence of toluene was undistinguishable whether it was generated from the pyrolysis of petrol or porcine bones. Meanwhile, the only pyrolytic key indicator of petrol; 1,2,4-trimethylbenzene was detected when the flames were manually extinguished. This work highlighted the role of experimental parameters such as the volume of petrol, burning duration and temperatures attained during the burning process, in addition to experimental methodology, that has exerted influence on the generation and detection of key pyrolytic products and on the burning characteristics of both petrol and porcine tissue. In order to obtain a more robust output in the future, this study could be executed in a combustion fume hood that facilitates consistent air flow, limiting the effects of insufficient and excessive oxygen supply. Besides that, the results from this study could also be put to the test in a full scale outdoor burning with the use of the entire pig carcass and surplus of petrol, emulating real life fire scenarios.

\section{References}

1. Saferstein, R. (2017). Criminalistics: An introduction to forensic science. $12^{\text {th }}$ edition. Pearson Education: pp. 524.

2. Adelson, L. (1955). Role of the pathologist in arson investigation. Journal of Criminal Law, Criminology \& Police Science, 45(6): 760 - 768.

3. Hine, G. A. (2004). Fire scene investigation: An introduction for chemists, in analysis and interpretation of fire scene evidence, K. G. F. Jose R. Almirall, CRC Press LLC: pp. 46.

4. Pert, A. D., Baron, M. G. and Birkett, J. W. (2006). Review of analytical techniques for arson residues. Journal of Forensic Sciences, 51(5): 1033 - 1049.

5. Jackowski, J. (1997). The incidence of ignitable liquid residues in fire debris as determined by a sensitive and comprehensive analytical scheme. Journal of Forensic Sciences, 42(5): 828 - 832.

6. Rumiza, A. R., Khairul, O., Zuha, R. M. and Heo, C. C. (2010). An observation on the decomposition process of gasoline-ingested monkey carcasses in a secondary forest in malaysia. Tropical Biomedicines, 27(3): 373 383.

7. Stauffer, E. (2003). Concept of pyrolysis for fire debris analysts. Science \& Justice, 43(1): 29 - 40.

8. Dehaan, J. D., Brien, D. J. and Large, R. (2004). Volatile organic compounds from the combustion of human and animal tissue. Science and Justice, 44(4): 223 - 236.

9. Gabriel, G. F. (2015). The analysis and discrimination of pyrolysis products from biological and non-biological sources. Thesis of Doctor Philosophy Degree, University of Strathclyde.

10. Mclellan, S. A. (1999). An investigation of the volatiles produced from pyrolysis of the body. Thesis of Master Degree, University of Strathclyde.

11. Agu, K. (2011). Investigation of the thermal degradation products of bon. Thesis of Doctor Philosophy Degree, University of Strathclyde.

12. Gabriel, G. F., Ismail, A., Abdul Ghani, A. A., Osman, K. and Noor Hazfalinda, H. (2017). The analysis of thermal decomposition products generated from porcine tissues exposed to outdoor burning conditions. Malaysian Journal of Analytical Sciences, 21(3): 585 - 596.

13. Dehaan, J. D., Taormina, E. I. and Brien, D. J. (2017). Detection and characterization of volatile organic compounds from burned human and animal remains in fire debris. Science \& Justice, 57(2): 118 - 127.

14. Purevsuren, B., Avid, B., Gerelmaa, T., Davaajav, Y., Morgan, T. J., Herod, A. A. and Kandiyoti, R. (2004). The characterisation of tar from the pyrolysis of animal bones. Fuel, 83(7): 799 - 805.

15. Almirall, J. R. and Furton, K. G. (2004). Characterization of background and pyrolysis products that may interfere with the forensic analysis of fire debris. Journal of Analytical and Applied Pyrolysis, 71 (1): 51 - 67.

16. Cavanagh, K., Pasquier, E. D. and Lennard, C. (2002). Background interference from car carpets-the evidential value of petrol residues in cases of suspected vehicle arson. Forensic Science International, 125(1): $22-36$.

17. Wineman, P. L. and Keto, R. O. (1994). Target-compound method for the analysis of accelerant residues in fire debris. Analytica Chimica Acta, 288(1): 97 - 110.

18. Lennard, C. J., Tristan Rochaix, V., Margot, P. and Huber, K. (1995). A GC-MS database of target compound chromatograms for the identification of arson accelerants. Science \& Justice, 35(1): 19 - 30.

19. Sferopoulos, R. (2013). Test burning of carpet and foam and potential interferences in identifying petrol in arson investigation by gas chromatography/ mass spectrometry. Thesis of Doctor Philosophy Degree, Victoria University. 
20. American Society of Testing and Materials E1618-06 (2006). ASTM E1618-06 standard test method for ignitable liquid residues in extracts from fire debris samples by Gas Chromatography-Mass Spectrometry. American Society of Testing and Materials. 11.

21. Rus Din, R. D., Zainal Ariffin, S. H., Senafi, S., Abdul Wahab, R. M. and Zainol Abidin, I. Z. (2014). Molecular mitochondrial DNA and radiographic approaches for human archaeology identification. Sains Malaysiana, 43(10): 1523 - 1535.

22. Arora, A., Gupta, P., Kapoor, S. and Mahajan, S. (2010). An analytic review of burnt bones in medicolegal sciences. Journal of Punjab Academy of Forensic Medicine \& Toxicology, 10: 31 - 36.

23. American Society for Testing and Materials E1412-07 (2012). Astm E1412-07 standard practice for separation of ignitable liquid residues from fire debris samples by passive headspace concentration with activated charcoal. American Society for Testing and Materials.

24. Paczkowski, S. and Schütz, S. (2011). Post-mortem volatiles of vertebrate tissue. Applied Microbiology and Biotechnology, 91(4): 917 - 935.

25. Dehaan, J. D. and Nurbakhsh, S. (2001). Sustained combustion of an animal carcass and its implications for the consumption of human bodies in fires. Journal of Forensic Sciences, 46(5): 1076 -1081.

26. Dehaan, J. D. (2012). Sustained combustion of bodies: Some observations. Journal of Forensic Sciences, 57(6): $1578-1584$.

27. The National Fire Protection Association (2017). NFPA 921: Guide for fire and explosion investigations. Massachusetts: The National Fire Protection Association.

28. Welker, J. R. and Sliepcevich, C. M. (1966). Burning rates and heat transfer from wind-blown flames. Fire Technology, 2(3): 211 - 218.

29. Chee Hau, T., Amir Hamzah, S. P. A., Khairul, O. and Noor Hazfalinda, H. (2013). Post mortem changes in relation to different types of clothing. Malaysian Journal of Pathology, 35(1): 77 - 85.

30. John D. Dehaan, D. J. I. (2011). Kirk's Fire Investigation. $8^{\text {th }}$ edition. Pearson.

31. Osman, K., Noor Hazfalinda, H. and Gabriel, G. F. (2018). Penyiasatan forensik: Pengecaman identiti penjenayah. Penerbit Universiti Kebangsaan Malaysia: pp. 103. 